\title{
Induction of resistance to Colletotrichum truncatum in lima bean
}

\section{Indução de resistência à Colletotrichum truncatum em feijão-fava}

\author{
Rommel dos Santos Siqueira Gomes ${ }^{1 *}$ (i), Luciana Cordeiro do Nascimento ${ }^{1}$
}

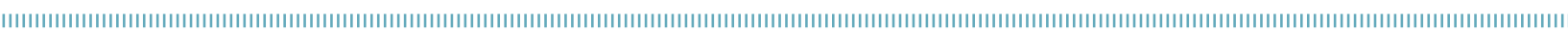

\begin{abstract}
Anthracnose (Colletotrichum truncatum) is one of the major diseases of the lima bean culture, found in production fields, causing decrease in productivity. The objective of this study was to evaluate the effect of abiotic and biotic inducers applied in lima bean plants to reduce anthracnose severity. Lima bean accessions were used and treated with: the abiotic inducers calcium silicate (Agrosilício Plus) and silicate clay (Rocksil), using the $3 \mathrm{~g}$ dose. $\mathrm{L}^{-1}$; the biotic inducer citric biomass extract (Ecolife), at the dose of $3 \mathrm{~mL} . \mathrm{L}^{-1}$; and distilled water as control. To evaluate the resistance induction, the results of severity and degree of resistance of fava bean at $7,11,15,19$ and 23 days after inoculation were considered according to the scale of grades and classes of reactions. The design was a randomized block in a factorial arrangement $4 \times 15$ (treatments $\times$ hits) with four blocks. Resistance inducers Agrosilicon Plus, Ecolife and Rocksil have potential to be used in the management of anthracnose in fava bean. The studied accesses showed degree of resistance, being able to be explored in relation to obtaining anthracnose resistant cultivars in future breeding programs of this crop.
\end{abstract}

KEYWORDS: Phaseolus lunatus; anthracnose; resistance inducer; severity.
RESUMO: A antracnose é uma das principais doenças da cultura do feijão-fava (Phaseolus lunatus L.), sendo encontrada em campos de produção e com grande potencial de causar redução na produtividade. O objetivo do trabalho foi determinar o efeito de indutores abiótico e biótico aplicados em plantas de feijão-fava, a fim de diminuir a severidade da antracnose. Foram utilizados 15 acessos de feijão-fava, tratados com os indutores abióticos: silicato de cálcio (Agrosilício Plus) e argila silicatada (Rocksil), utilizando a dose de 3 g. $\mathrm{L}^{-1}$ para ambos os produtos; e o indutor biótico biomassa cítrica (Ecolife), na dose de 3 mL.L-1 . Como testemunha, aplicou-se apenas água destilada. Para avaliar a indução de resistência, foram considerados os resultados de severidade e grau de resistência dos acessos de feijão-fava aos 7, 11, 15, 19 e 23 dias após a inoculaçáo, de acordo com escala de notas e classes de reaçóes. O delineamento utilizado foi em blocos casualizados, em arranjo fatorial simples $4 \times 15$ (tratamentos $\times$ acessos) com quatro blocos. Os indutores de resistência Agrosilício Plus, Ecolife e Rocksil apresentaram potencial para serem utilizados no manejo da antracnose em feijão-fava. Os acessos estudados revelaram grau de resistência, podendo ser explorados quanto à obtenção de cultivares resistentes à antracnose em futuros programas de melhoramento genético dessa cultura.

PALAVRAS-CHAVE: Phaseolus lunatus; antracnose; indutor de resistência; severidade. 


\section{INTRODUCTION}

Lima bean (Phaseolus lunatus L.) is the second most important legume of the genus due to its high-quality protein content, making it an excellent food option and source of revenue for small farmers (SOARES et al., 2010). Lima beans are grown in different states in Brazil, especially in the northeastern region of the country. The state of Paraíba is considered the national producer of this legume (IBGE, 2014). However, productivity is low due mainly to inadequate management, as well as the occurrence of pests and diseases.

Anthracnose caused by the fungus Colletotrichum truncatum is among the diseases that have caused considerable harm to lima bean crops. This disease can cause losses of up to $100 \%$ in the production and quality of the pods, compromising the commercialization of the beans (DAMM et al., 2009).

The incidence of phytopathogens is controlled by chemical means, the use of more resistant varieties and the adoption of crop control methods (MÉLO-FILHO; GUENTHBER, 2015). With regard to chemical control, there are no products registered for the management of anthracnose on lima bean plants. Therefore, the use of more resistance varieties is recommended, which are obtained through conventional improvement methods or genetic engineering (transgenic methods), and the adoption of traditional growing methods, such as crop rotation.

The induction of resistance is a promising complementary alternative to conventional chemical and genetic control that minimizes the disadvantages related to the excessive use of pesticides (chemical control). This process also reduces the probability of fungi overcoming vertical resistance (FERNANDES, 2007), as a result of the considerable intrinsic variability in the organisms.

Resistance inducers in plants are classified as either biotic or abiotic, depending on their mode of action. Biotic inducers are living organisms or parts of living organisms that trigger defense processes, provoking localized and systemic reactions in plants. Abiotic inducers may be synthetic molecules that mimic the signal of the pathogen, thereby activating defense genes responsible for the increase in the production of secondary metabolites, such as phenolic compounds, phytoalexins and salicylic acid. Abiotic inducers also include external factors, such as injury or other forms of stress caused by temperature, ultraviolet (UV) radiation or salinity (ATHAYDE SOBRINHO et al., 2005).

A number of substances has been used to induce resistance, such as acibenzolar-S-methyl, phosphate and citric biomass. However, few studies have been conducted on the use of such substances for the development of resistance to anthracnose in lima bean plants. Therefore, the aim of the present study was to determine the effects of biotic and abiotic inducers on the induction of resistance in lima bean plants to C. truncatum.

\section{MATERIALS AND METHODS}

\section{Resistance inducers}

The treatments consisted of the abiotic inducers calcium silicate (Agrosilício Plus) and silicate clay (Rocksil), as well as the biotic inducer Ecolife, which is made from a commercial extract of citric biomass. Control plants were treated with sterilized distilled water. Table 1 lists the products used in this study.

\section{C. truncatum isolate}

The C. truncatum isolate denominated CT35 was obtained from the collection of the Phytopathology Laboratory of the Federal University of Paraíba, Brazil, which was preserved in CASTELLANI (1963). The inoculum was prepared by adding $10 \mathrm{~mL}$ of sterilized distilled water to Petri dishes containing the fungal colony cultivated in a bean-dextrose-agar medium at $27 \pm 2^{\circ} \mathrm{C}$, with a $12-\mathrm{h}$ photoperiod for 14 days. The conidia were removed with the aid of a platinum loop. The spore suspension was filtered through sterilized gauze, and the concentration of conidia was adjusted to $1 \times 10^{6}$ colony-forming units. $\mathrm{mL}^{-1}$, using a Neubauer chamber.

The experiment was conducted in a greenhouse using seeds from 15 lima bean (P. lunatus L.) production fields (Areia, Alagoa Grande, Campina Grande, Alagoa Nova, Queimadas, Massaranduba and Remígio) in the state of Paraíba, Brazil, deposited in the seed bank of the university (Fig. 1).

The seeds were sowed in polypropylene pots containing $3 \mathrm{dm}^{3}$ of soil collected from a lima bean field. Five seeds were used per pot after treatment with the fungicide Captan $(240 \mathrm{~g}$ i.a. $100 \mathrm{~kg}$ of seeds). The first irrigation was performed at $60 \%$ of the moisture capacity of the soil, with additional watering every $72 \mathrm{~h}$. The pots were kept under greenhouse conditions with the temperature ranging from 20.4 to $39.4^{\circ} \mathrm{C}$. After emergence,

Table 1. Description of treatments based on resistance inducers used in the study.

\begin{tabular}{|c|c|c|c|}
\hline Products & Manufacturer & $\begin{array}{l}\text { Chemical } \\
\text { composition }\end{array}$ & Dose \\
\hline $\begin{array}{l}\text { Agrosilício } \\
\text { Plus }\end{array}$ & Agronelli & $\begin{array}{c}\text { 34,9\% } \mathrm{CaO} ; 25 \% \\
\mathrm{Ca} ; 9,9 \% \mathrm{MgO} ; 6 \% \\
\mathrm{Mg} ; 22,4 \% \mathrm{SiO}_{2} \\
10,5 \% \mathrm{Si}\end{array}$ & $3 \mathrm{~g} \cdot \mathrm{L}^{-1}$ \\
\hline Ecolife & Quinabra & $\begin{array}{c}\text { Bioflavonoids, } \\
\text { ascorbic acid, lactic } \\
\text { acid and vegetable } \\
\text { glycerin }\end{array}$ & $3 \mathrm{~mL} \cdot \mathrm{L}^{-1}$ \\
\hline Rocksil & Lia Ulmasud & $\begin{array}{c}20,6 \% \mathrm{Al}_{2} \mathrm{O}_{3} ; \\
17,4 \% \mathrm{SiO}_{2} ; 9,8 \% \\
\mathrm{~S} ; 1,3 \% \mathrm{CaO} ; 0,3 \% \\
\mathrm{TiO}_{2} ; \mathrm{O}, 2 \% \mathrm{MgO} ; \\
\mathrm{O}, 2 \% \mathrm{Fe}_{2} \mathrm{O}_{3} ; 0,1 \% \\
\mathrm{P}_{2} \mathrm{O}_{5}\end{array}$ & $3 \mathrm{~g} \cdot \mathrm{L}^{-1}$ \\
\hline
\end{tabular}


seedlings with normal development were selected, leaving two plants per pot. Each treatment consisted of ten replicates.

\section{Induction of resistance to $C$. truncatum}

The treatments were applied directed to the abaxial and adaxial faces of the trifoliate leaves to the point of runoff, with the aid of a manual sprayer (Guarany) with a 5 -liter capacity. Three applications were performed at 15-day intervals; the first of them was performed 15 days after sowing (DAS). Inoculation was performed 46 DAS on leaves in the V3 phenological stage (primary trifoliate leaf) that had previously been marked with a nylon string. The inoculum was applied with a sprayer containing $1.5 \mathrm{~mL}$ of the suspension of $1 \times 10^{6}$ colony forming units. $\mathrm{mL}^{-1}$. The leaves then remained in a humidity chamber for $24 \mathrm{~h}$ in transparent polyethylene bags and moistened with water. The plants remained in the greenhouse at a temperature from 20.4 to $39.4^{\circ} \mathrm{C}$ and relative humidity ranging from 34 to $83 \%$. Temperature and relative humidity data were recorded using a digital thermohygrometer throughout the evaluation period. Control plants were maintained under the same conditions described for the treated plants.

\section{Severity of anthracnose on lima bean plants}

Anthracnose severity was evaluated 7, 11, 15, 19 and 23 days after inoculation (DAI) and scored from 0 to 5 using the classification system proposed by CARVALHO (2009):
- $0=$ absence of symptoms;

- $1=10 \%$ of leaf area infected;

- $2=11$ to $25 \%$ of leaf area infected;

- $3=26$ to $50 \%$ of leaf area infected, without shedding of leaflets;

- $4=51$ to $75 \%$ of leaf area infected, without or with shedding of one of the leaflets;

- $5=76$ to $100 \%$ of leaf area infected, without or with shedding of two or three leaflets.

\section{Degree of resistance of lima bean plants}

Based on the results of anthracnose severity, the plants were classified with regard to the reaction to the CT35 isolate using the system proposed by BELMINO (2004):

- 0 = immune (IM);

- $\quad$ to $1.4=$ highly resistant $(\mathrm{HR})$;

- 1.5 to 2.4 moderately resistant (MR);

- 2.5 to $3.0=$ moderately susceptible (MS);

- $3.0=$ highly susceptible (HS).

\section{Statistical analysis}

A random-block experimental design was employed with a simple $4 \times 15$ (treatments $\times$ plants) factorial arrangement with four block. Means were compared using the Scott-Knott test with $5 \%$ probability in the R software (R DEVELOPMENT CORE TEAM, 2018).
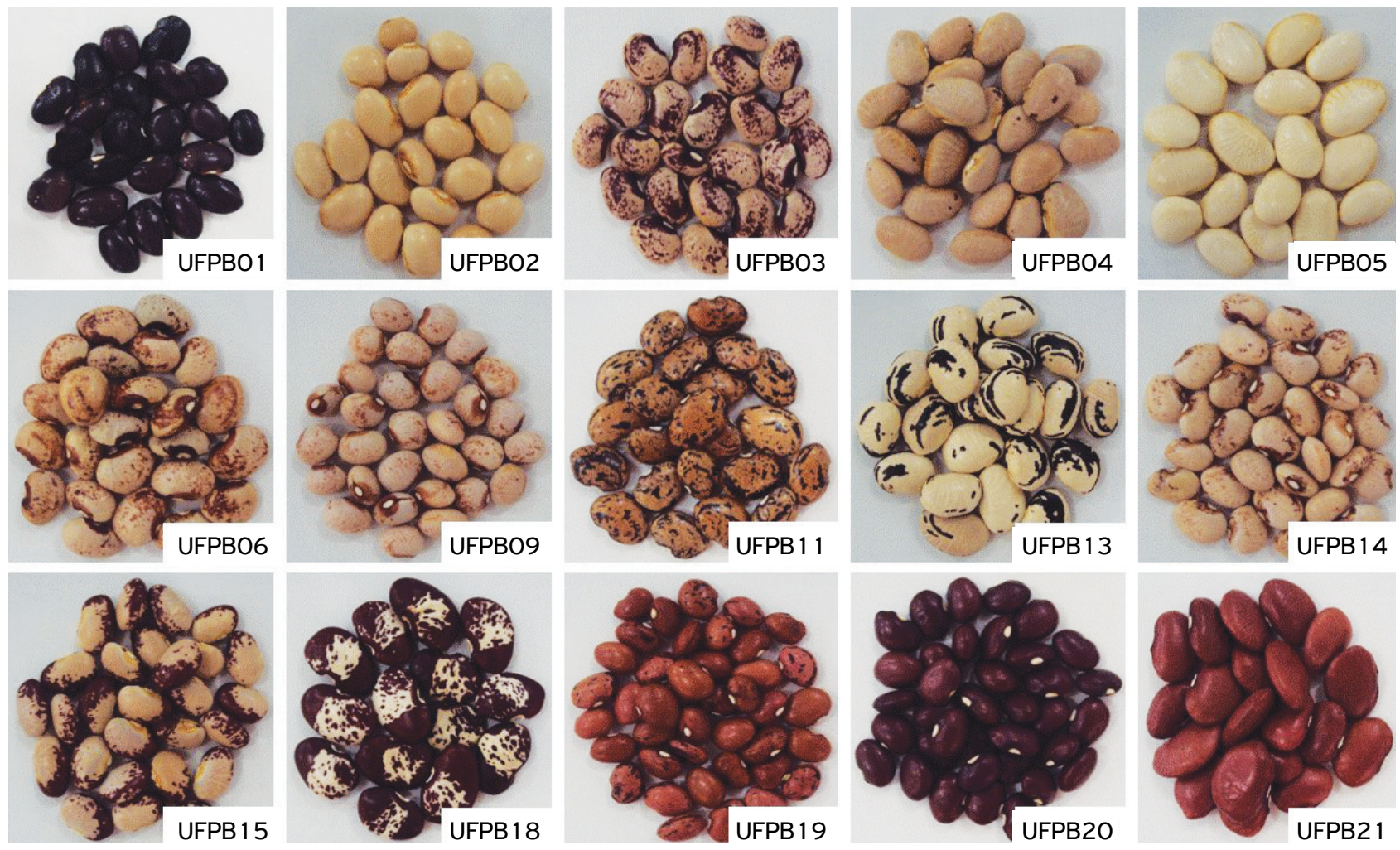

Figure 1. Accessions of fava bean (Phaseolus lunatus L.) cultivated in greenhouse. The plants were treated with resistance inducers and artificially inoculated with Colletotrichum truncatum. 


\section{RESULTS AND DISCUSSION}

No significant sample-treatment interaction was found. However, significant differences were found among the treatments with regard to anthracnose severity $(\mathrm{p}<0.001)$.

Less severity was found on the lima bean plants (except samples UFPB03 and UFPB11) in the treatments with calcium silicate (Agrosilício Plus) and silicate clay (Rocksil), which were considered the most effective treatments. When submitted to treatment with calcium silicate, significant reductions were found in the UFPB03, UFPB09 and UFPB19 samples, reaching values of 3.4, 1.5 and 0.9 , respectively (Fig. 2).

The present results are similar to the findings described by MORAES et al. (2006), who studied the effect of different silicate sources. The authors evaluated anthracnose severity on the common bean plant (Phaseolus vulgaris L.) caused by Colletotrichum lindemuthianum after the application of calcium silicate. PEREIRA et al. (2009) found out that the application of potassium silicate to the leaves of coffee plants infected with Hemileia vastatrix led to an increase in the activities of quitinase (QUI) and glucanase (GLU) in intermediate stages of the infectious process. According to GUERRA et al. (2013), the activities of these two enzymes may be related to the defense mechanisms of plants suppressed with $\mathrm{Si}$, impeding the pathogen from entering, growing and colonizing the cells of the leaf tissue. In a previous study, Si enhanced the resistance to the coffee plant pathogen Cercospora coffeicola, with increase in cuticle thickness (POZZA et al., 2004). This increase is due mainly to the formation of a thicker layer of epicuticular wax, which hinders the penetration of the pathogen through the cuticle or stomata (POZZA et al., 2004; BRANCAGLIONE et al., 2009). It is possible that similar structures were induced in the lima bean leaves treated with calcium silicate in the present investigation, but further studies are needed to confirm this possibility.

The treatment with the citric biomass (Ecolife) had a similar effect among the samples, with lower severity in comparison to

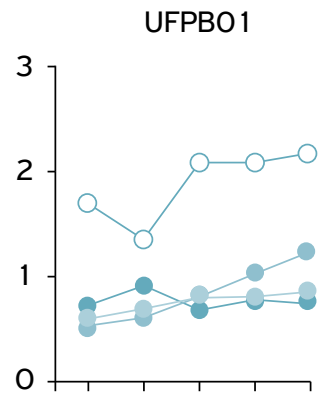

UFPBO6

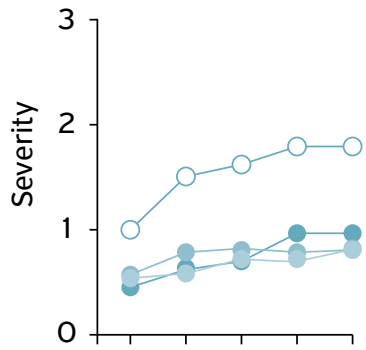

UFPB 15

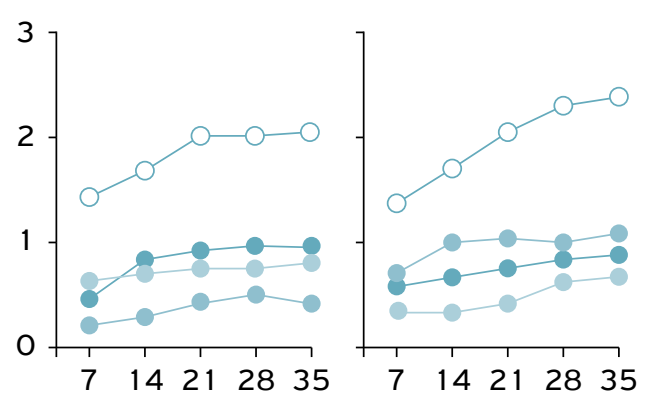

Agrosilício Plus

UFPBO3

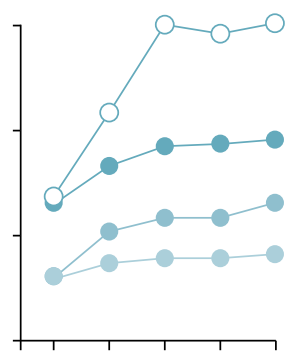

UFPBO9

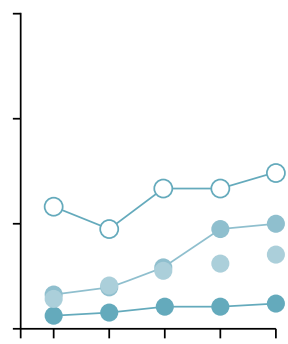

UFPB 18

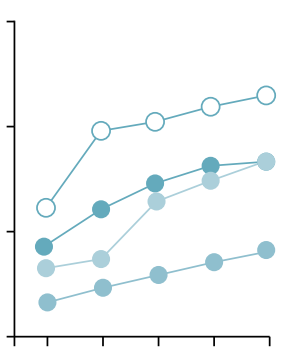

UFPB 11

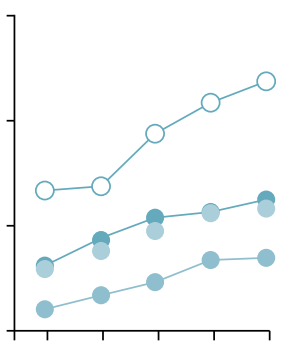

UFPB 19

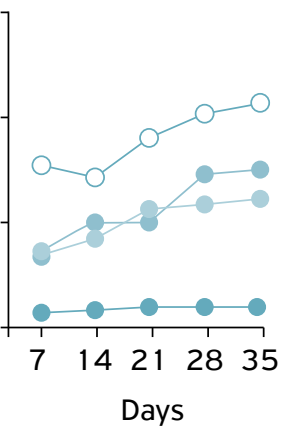

Ecolife
UFPBO4

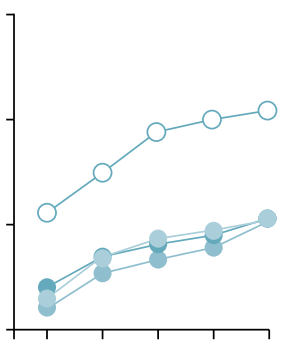

UFPB 13

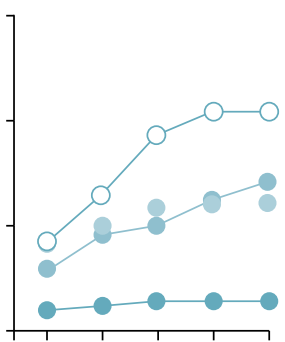

UFPB2O

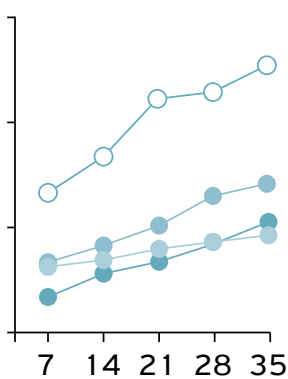

Rocksil
UFPBO5

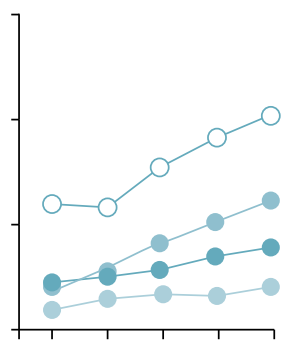

UFPB 14

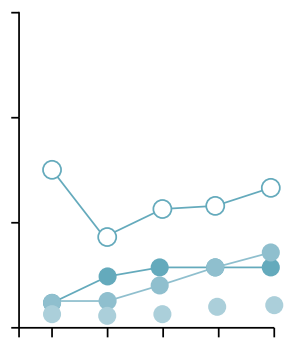

UFPB2 1

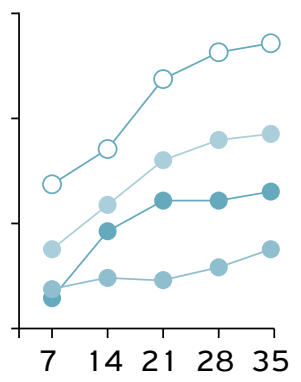

Control plants

Figure 2. Effect of treatments with resistance inducers on the reduction of anthracnose severity in lima bean accessions (Phaseolus lunatus L.) grown under conditions greenhouse. 
the control plants (Fig. 2). Moreover, a considerable reduction in anthracnose was found in four of the samples (UFPB01, UFPB04, UFPB05 and UFPB18). These results are similar to findings described by FARIA et al. (2011), who investigated the effect of applying citric biomass to the parthenocarpic cumber (Cucumis sativus L.) for the control of Oidium spp. The authors reported no differences among the treatments, but found a reduction in the area under the curve of odium progression. FURTADO et al. (2010) reported the positive effect of citric biomass on reducing the severity of anthracnose (Colletotrichum spp.) in different varieties of banana plants. MOTOYAMA et al. (2003) detailed a similar effect of citric biomass (Ecolife 40), which exhibited eliciting activity and induced the synthesis of the phytoalexin glycoline in the cotyledons of soy plants (Glycine max L.) and deoxyanthocyanidins in the mesocotyls of sorghum plants (Sorghum bicolor (L.) Moench).

Treatment with silicate clay (Rocksil) was effective at considerably reducing the severity of anthracnose on the UFPB1 1 sample (Fig. 2), achieving the lowest minimum value (0.7) among all treatments used on this sample. BRANCAGLIONE et al. (2009) also found a significant effect of silicate clay on the preventive control of bacterial leaf spot (Xanthomonas axonopodis pv. Passiflorae) on seedlings of the yellow passion fruit plant (Passiflora edulis (Sims) f. flavicarpa (Deg.).

Taking into account the percentage of control achieved by the treatments (Fig. 2), greater control of anthracnose on lima bean plants was achieved with the application of the calcium silicate and silicate clay inducers, with greater than $90 \%$ efficiency in the UFPB03, UFPB09 and UFPB1 1 samples. Intermediate values (70 to $88 \%$ ) were found for the critic biomass and silicate clay in another seven samples (Fig. 2). These results are similar to findings described by BRANCAGLIONE et al. (2009), who reported that silicate clay achieved greater than $90 \%$ control of the severity of bacterial leaf spot (Xanthomonas axonopodis pv. Passiflorae) on yellow passion fruit plants (Passiflora edulis (Sims) f. flavicarpa (Deg.) used as preventive treatment.

Silicate based products contribute significantly to the reduction in the incidence of numerous diseases of economic importance. These diseases tend to diminish with the increase in the concentration of silicate applied to the leaf tissue (DATNOFF et al., 2007). SANTOS (2002) and PRATISSOLI et al. (2007) found a linear decrease in the severity of cercosporiosis (brown eye spot) on the coffee tree (Cercospora coffeicola) and black spot disease (Asperisporium caricae) on papaya trees with the application of calcium silicate and silicate clay. Rice plants (Oryza sativa L.) grown with increasing doses of this element exhibited reduction in the severity of sheath blight (Rhizoctonia solani) (RODRIGUES et al., 2002). RODRIGUES et al. (2003) also demonstrated increase in the concentration of phenolic compounds and phytoalexins.

For the control treatment, the UFPB21 had the greatest severity of anthracnose (Fig. 2). Moreover, the smallest control percentage in the same sample $(31 \%)$ was recorded with the application of calcium silicate (Fig. 2).

Considering the degree of resistance in the samples, a significant sample-DAI interaction was found $(\mathrm{p}<0.001)$. Despite the fact that no material was free of symptoms, differences in resistance were distinguished among the samples (Table 2).

Table 2. Severity and anthracnose degree of resistance between accesses lima bean (Phaseolus lunatus L.) days after inoculation.

\begin{tabular}{|c|c|c|c|c|c|c|c|c|c|c|c|c|c|c|c|}
\hline \multirow{2}{*}{ Accesses } & \multicolumn{3}{|c|}{7 DAl } & \multicolumn{3}{|c|}{$14 \mathrm{DAl}$} & \multicolumn{3}{|c|}{$21 \mathrm{DAl}$} & \multicolumn{2}{|c|}{28 DAl } & \multicolumn{4}{|c|}{$35 \mathrm{DAl}$} \\
\hline & $\mathbf{S}$ & & DR & $\mathbf{S}$ & & DR & $\mathbf{S}$ & & DR & $\mathbf{S}$ & & DR & $\mathbf{S}$ & & DR \\
\hline UFPBO 1 & 1.4 & $\mathrm{aA}$ & $\mathrm{HR}$ & 1.4 & $\mathrm{aA}$ & $\mathrm{HR}$ & 1.8 & $c A$ & MR & 2.1 & $\mathrm{aA}$ & MR & 2.2 & $\mathrm{aA}$ & MR \\
\hline UFPBO2 & 1.4 & $\mathrm{aC}$ & HR & 2.2 & $\mathrm{aC}$ & MR & 3.0 & $\mathrm{aA}$ & MS & 3.0 & $\mathrm{aA}$ & MS & 3.0 & $\mathrm{aA}$ & MS \\
\hline UFPBO3 & 1.3 & $\mathrm{aB}$ & $\mathrm{HR}$ & 2.0 & $\mathrm{aB}$ & MR & 2.2 & bA & MR & 2.3 & $\mathrm{aA}$ & MR & 2.4 & $\mathrm{aA}$ & MR \\
\hline UFPBO4 & 1.1 & $\mathrm{aB}$ & $\mathrm{HR}$ & 1.5 & $\mathrm{aB}$ & MR & 1.9 & $c A$ & MR & 2.0 & $\mathrm{aA}$ & MR & 2.1 & $\mathrm{aA}$ & MR \\
\hline UFPBO5 & 1.2 & $\mathrm{aA}$ & $\mathrm{HR}$ & 1.2 & $\mathrm{aA}$ & $\mathrm{HR}$ & 1.5 & $c A$ & MR & 1.8 & $\mathrm{aA}$ & MR & 2.0 & $\mathrm{aA}$ & MR \\
\hline UFPBO6 & 0.9 & $\mathrm{aB}$ & HR & 1.4 & $\mathrm{aB}$ & HR & 1.8 & $c A$ & MR & 1.9 & $\mathrm{aA}$ & MR & 1.9 & $\mathrm{aA}$ & MR \\
\hline UFPBO9 & 1.0 & $\mathrm{aA}$ & HR & 1.0 & $\mathrm{aA}$ & $\mathrm{HR}$ & 1.3 & $c A$ & $\mathrm{HR}$ & 1.3 & bA & $\mathrm{HR}$ & 1.4 & bA & HR \\
\hline UFPB 11 & 1.2 & $\mathrm{aB}$ & $\mathrm{HR}$ & 1.4 & $\mathrm{aB}$ & $\mathrm{HR}$ & 1.9 & $c A$ & MR & 2.1 & $\mathrm{aA}$ & MR & 2.3 & $\mathrm{aA}$ & MR \\
\hline UFPB 13 & 0.8 & $\mathrm{aB}$ & HR & 1.2 & $\mathrm{aB}$ & $\mathrm{HR}$ & 1.8 & $c A$ & MR & 2.0 & $\mathrm{aA}$ & MR & 2.0 & $\mathrm{aA}$ & MR \\
\hline UFPB 14 & 0.9 & $\mathrm{aA}$ & HR & 0.9 & $\mathrm{aA}$ & HR & 1.0 & $c A$ & HR & 1.0 & bA & HR & 1.2 & bA & AR \\
\hline UFPB 15 & 1.3 & $a A$ & HR & 1.5 & $\mathrm{aA}$ & MR & 2.0 & $c A$ & MR & 2.0 & $a A$ & MR & 2.0 & $\mathrm{aA}$ & MR \\
\hline UFPB 18 & 1.3 & $\mathrm{aB}$ & HR & 1.6 & $\mathrm{aB}$ & MR & 2.0 & $c A$ & MR & 2.2 & $a A$ & MR & 2.3 & $a A$ & MR \\
\hline UFPB 19 & 1.3 & $\mathrm{aA}$ & HR & 1.3 & $\mathrm{aA}$ & $\mathrm{HR}$ & 1.7 & $c A$ & MR & 1.9 & $\mathrm{aA}$ & MR & 2.0 & $\mathrm{aA}$ & MR \\
\hline UFPB2O & 1.2 & $\mathrm{aB}$ & $\mathrm{HR}$ & 1.5 & $\mathrm{aB}$ & MR & 2.1 & bA & MR & 2.2 & $\mathrm{aA}$ & MR & 2.4 & $\mathrm{aA}$ & MR \\
\hline UFPB2 1 & 1.3 & $\mathrm{aB}$ & $\mathrm{HR}$ & 1.6 & $\mathrm{aB}$ & MR & 2.3 & bA & MR & 2.5 & $\mathrm{aA}$ & MS & 2.6 & $\mathrm{aA}$ & MS \\
\hline CV\% & & & & & & & & & & & & & & & \\
\hline
\end{tabular}

DAI: days after inoculation; S: severity; DR: degree of resistance; HR: highly resistant; MR: moderately resistant; MS: moderately susceptible; $\mathrm{CV}$ : coefficient of variation. 
At the end of the evaluation period (35 DAI), 74\% of the samples exhibited moderately resistant (MR) reaction, $13 \%$ exhibited moderately susceptible (MS) reaction, and $13 \%$ were classified as highly resistant (HR) to anthracnose. These findings are in agreement with data reported by CAVALCANTE et al. (2012), who evaluated the resistance reaction to $C$. truncatum among 30 subsamples of lima bean plants.

The UFPB09 and UFPB19 samples differed significantly from the other samples and were classified as having highly resistant (HR) reaction, with severity scores of 1.0 to 1.4 and 1.3 to 2.0, respectively (Table 2). Reaction scores of 1.5 to 2.4 were considered MR among the samples studied, and the reaction corresponding to MS was expressed by the UFPB02 and UFPB21 samples, with minimum severity scores of 1.3 and 1.4 and maximum severity scores of 3.0 and 2.6, respectively (Table 2). Therefore, one may infer that the different samples have different degrees of susceptibility to anthracnose, but there are also sources of resistance to this disease among the samples studied.

BELMINO (2004) reported variations in resistance to $C$. truncatum among genotypes of the cowpea (Vigna unguiculata (L.) Walp.). The author found that the reaction to the isolates evaluated ranged from highly susceptible to the absence of symptoms. Likewise, CARMO et al. (2015) evaluated the reaction of 12 samples of lima bean plants to anthracnose using detached leaves, and the results revealed that two samples (UFPI641 and UFPI644) were classified at HR at five DAI, but a change occurred in the reaction level to MR at
7 DAI. Evaluating 48 commercial soybean varieties (Glycine max L.) under greenhouse conditions, COSTA et al. (2009) found 16 genotypes resistant to $C$. truncatum.

All classes of reactions were found among the samples as a consequence of the variability in resistance and the conditions of the environment used in the evaluations. Thus, the samples exhibited different degrees of resistance to anthracnose and could be explored in future studies as sources of resistance together with studies on the virulence structuring of $C$. truncatum.

\section{CONCLUSION}

The resistance inducers Agrosilicon Plus, Ecolife and Rocksil demonstrate potential for use in the management of anthracnose on lima bean plants.

The samples studied exhibited different degrees of resistance and should be investigated further with respect to obtaining varieties that are resistant to anthracnose in future genetic improvement programs for this crop.

\section{ACKNOWLEDGMENTS}

To Brazilian Federal Agency for Post-graduate Education (CAPES, Brazil) for the financial support of the research.

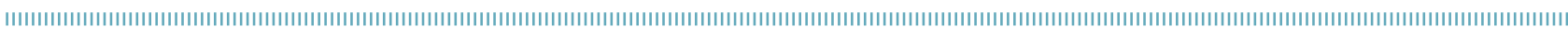

\section{REFERENCES}

ATHAYDE SOBRINHO, C.; FERREIRA, P.T.O.; CAVALCANTI, L.S. Indutores abióticos. In: CAVALCANTI, L.S.; DI PIERO, R.M.; CIA, P.; PASCHOLATI, S.F.; RESENDE, M.L.V.; ROMEIRO, R.S. (Eds.). Indução de resistência a patógenos e insetos. $1^{\text {a }}$ ed. Piracicaba: FEALQ, 2005. p.51-80.

BELMINO, C.S. Resistência do feijão-caupi à Colletotrichum truncatum. 2004. 64f. Tese (Doutorado em Fitopatologia) Universidade Federal de Viçosa, Viçosa, 2004.

BRANCAGLIONE, P.; SAMPAIO, A.C.; FISCHER, I.H.; ALMEIDA, A.M.; FUMIS, T.F. Eficiência de argila silicatada no controle de Xanthomonas axonopodis pv. passiflorae, in vitro e em mudas de maracujazeiro-amarelo. Revista Brasileira de Fruticultura, v.31, n.3, p.718-724, 2009. http://dx.doi.org/10.1590/ so $100-29452009000300014$

CARMO, M.D.S.; CARVALHO, E.M.S.; GOMES, R.L.F.; LOPES, A.C.A.; CAVALCANTE, G.R.S. Avaliação de acessos de feijão-fava, para resistência a Colletotrichum truncatum, em condições de folhas destacadas e campo. Summa Phytopathologica, v.41, n.4, p.292297, 2015. http://dx.doi.org/10.1590/0100-5405/2079
CARVALHO, E.M.S. Antracnose em feijão-fava (Phaseolus lunatus L.): caracterização do agente causal e reação de genótipos a Colletotrichum truncatum. 2009. 53f. Tese (Doutorado em Agronomia) - Faculdade de Ciências Agrárias e Veterinárias, Universidade Estadual Paulista, Jaboticabal, 2009.

CASTELLANI, A. The "water cultivation" of pathogenic fungi. Journal of Tropical Medicine and Hygiene, v.66, n. 1, p.283-284, 1963.

CAVALCANTE, G.R.S.; CARVALHO, E.M.S.; GOMES, R.L.F.; SANTOS, A.R.B.; SANTOS, C.M.P.M. Reação de subamostras de feijão-fava à antracnose. Summa Phytopathologica, v.38, n.4, 329-333, 2012. http://dx.doi.org/10.1590/SO100-54052012000400010

COSTA, I.F.D.; BALARDIN, R.S.; MEDEIROS, L.A.M.; LENZ, G.; GULART, C.A.; ZEMOLIn, C.R.; SILVA, T.M.B. Reação de germoplasma comercial de soja a Colletotrichum truncatum. Tropical Plant Pathology, v.34, p.47-50, 2009. http://dx.doi.org/10.1590/ S1982-56762009000100009

DAMM, U.; WOUDENBERG, J.H.C.; CANNON, P.F.; CROUS, P.W. Colletotrichum species with curved conidia from herbaceous hosts. Fungal Diversity, v.39, p. 45-87, 2009. 
DATNOFF, L.E.; RODRIGUES, F.A.; SEEBOLD, K.W. Silicon and plant disease. In: DATNOFF, L.E.; ELMER, W.H.; HUBER, D.M. (Ed.). Mineral Nutrition and Plant Disease. St. Paul: APS Press, 2007. 246p.

FARIA, G.S.; VIDA, J.B.; VERZIGNASSI, J.R.; TESSMANN, D.J.; LORENZETTI, E.R.; GASPAROTTO, F. Controle de oídio em pepino partenocárpico com produtos alternativos em cultivo protegido. Summa Phytopathologica, v.37, n.4, p.205-207, 2011 . http:// dx.doi.org/10.1590/SO100-54052011000400008

FERNANDES, W.S. Respostas de defesa e resistência induzida por ulvana à antracnose (Colletotrichum lindemuthianum) em cultivares de feijoeiro comum (Phaseolus vulgaris L.). Florianópolis. 2007. 85f. Dissertação (Mestrado em Recursos Genéticos Vegetais) Universidade Federal de Santa Catarina, Florianópolis, 2007.

FURTADO, L.M.; RODRIGUES, A.A.C.; ARAÚJO, V.S.; SILVA, L.L.S.; CATARINO, A.M. Utilização de Ecolife e Acibenzolar-s-metil (ASM) no Controle da Antracnose da banana em pós-colheita. Summa Phytopathologica, v.36, n.3, p.237-239, 2010. http://dx.doi. org/10.1590/S0100-54052010000300009

GUERRA, A.M.N.M.; RODRIGUES, F.A.; BERGER, P.G.; BARROS, A.F.; RODRIGUES, Y.C.; LIMA, T.C. Resistência do algodoeiro à ferrugem tropical potencializada pelo silício. Bragantia, v.72, n.3, p.279-291, 2013. http://dx.doi.org/10.1590/brag.2013.037

INSTITUTO BRASILEIRO DE GEOGRAFIA E ESTATÍSTICA (IBGE). Produção agrícola municipal: culturas temporárias e permanentes. 2014. Available from: <https://biblioteca.ibge. gov.br/visualizacao/periodicos/66/pam_2014_v41_br.pdf $>$. Access on: 15 Dec. 2017.

MÉLO-FILHO, L.R.; GUENTHER, M.A. Resistência sistêmica induzida como alternativa sustentável ao uso de agrotóxicos. Revista em Agronegócio e Meio Ambiente, v.8, n.27, p. 27-38, 2015. DOI: 10.17765/2176-9168.2015v8nEd.esp.p27-38

MORAES, S.R.G.; POZZA, E.A.; ALVES, E.; POZZA, A.A.A.; CARVALHO, J.G.; LIMA, P.H.; BOTELHO, A.O. Efeito de fontes de silício na incidência e na severidade da antracnose do feijoeiro. Fitopatologia Brasileira, v.31, n. 1, p.69-75, 2006. http://dx.doi. org/10.1590/SO100-41582006000100012

MOTOYAMA, M.M.; SCHWAN-ESTRADA, K.R.F.; STANGARLIN, J.R.; FIORI-TUTIDA, A.C.G.; SCAPIM, C.A. Indução de fitoalexinas em soja e em sorgo e efeito fungitóxico de extratos cítricos sobre Colletotrichum lagenarium e Fusarium semitectum. Acta Scientiarum Agronomy, v.25, n.2, p.491-496, 2003. DOI: 10.4025/actasciagron.v25i2.2062

PEREIRA, S.C.; RODRIGUES, F.A.; CARRÉ-MISSIO, V.; OLIVEIRA, M.G.A.; ZAMBOLIM, L. Efeito da aplicação foliar de silício na resistência à ferrugem e na potencialização da atividade de enzimas de defesa em cafeeiro. Tropical Plant Pathology, v.34, n.4, p.223-230, 2009. http://dx.doi.org/10.1590/ S1982-56762009000400004

POZZA, A.A.A.; ALVES, E.; POZZA, E.A.; CARVALHO, J.G.; MONTANARI, M.; GUIMARÃES, P.T.G.; SANTOS, D.M. Efeito do silício no controle da cercosporiose em três variedades de cafeeiro. Fitopatologia Brasileira, v.29, n.2, p.185-188, 2004. http://dx.doi.org/10.1590/SO100-41582004000200010

PRATISSOLI, D.; DIAS DE ALMEIDA, G.; JESUS JÚNIOR, W.C.; VICENTINI, V.B.; HOLTZ, A.M.; COCHETO, J.G. Fertilizante organomineral e argila silicatada como indutores de resistência à varíola do mamoeiro. Idesia (Arica), v.25, n.2, p.63-67, 2007. http://dx.doi.org/10.4067/S07 18-34292007000200008

R DEVELOPMENT CORE TEAM. R: a language and environment for statistical computing. Vienna, Austria: R Foundation for Statistical Computing. Available from: <https://www.R-project. org>. Access on: 15 Jun. 2018.

RODRIGUES, F.A.; BENHAMOU, N.; DATNOFF, L.E.; JONES, J.B.; BÉLANGER, R.R. Ultra structural and cytochemical aspects of silicon medi atedriceblastre sistance. Phytopathology, v.93, n.5, p.535-546, 2003. DOI: 10.1094/PHYTO.2003.93.5.535

.; VALE, F.X.R.; KORNDÖRFER, G.H.; PRABHU, A.; DATNOFF, L.E.; OLIVEIRA, A.M.A.; ZAMBOLIM, L. Influence of silicon on sheath blight of rice in Brazil. Crop Protection, v.22, n.1, p.2329, 2002. DOI: 10.1016/SO261-2194(02)00084-4

SANTOS, D.M. Efeito do silício na intensidade da cercosporiose Cercospora coffeicola (Berk. \& Cooke) em mudas de cafeeiro (Coffea arabica L.). 2002. 43f. Tese (Doutorado em Fitopatologia) - Universidade Federal de Lavras, Lavras, 2002.

SOARES, C.A.; LOPES, A.C.A.; GOMES, R.L.F.; GÂNDARA, F.C. Aspectos socioeconômicos. In: LOPES, A.C.A.; GOMES, R.L.F.; ARAÚJO, A.S.F. (Orgs.). A cultura do feijão-fava no Meio Norte do Brasil. Teresina: EDUFPI, 2010. p.237-263. 